\title{
Thwarted expectations of divine reciprocity
}

\section{Saskia Peels}

Université de Liège, Sciences de l'Antiquité, 7 place du XX-Août, B-4000 Liège s.peels@ulg.ac.be

\begin{abstract}
The notion of reciprocity in Greek religion has been approached from many angles. One question that has not been treated concerns human discontent at gods' gifts. Given that, in Greek literature, characters conceptualised their relationship with gods as a bond of reciprocal $\chi \alpha$ ópıs, did these fictive characters use the same conceptual frame in talking about frustrated expectations of divine reciprocity? When gods did not give in return what had been hoped for, was such disappointment ever constructed as a case of dysfunctional reciprocity? In this paper I argue that the answer is 'no', but a conscious no. Explicit disappointment in divine reciprocity occurs, but exclusively under 'special circumstances'. Such criticism is uttered by characters who are not Greek, for example, who are portrayed as having rather strange views anyway, or who have a very special reciprocal relationship with a god based on divine parenthood of a human child. The distribution and nature of complaints shows that reproaching gods about disappointed reciprocity was consciously considered as very un-Greek.
\end{abstract}

\section{Keywords}

Greek religion, reciprocity, tragedy

In Hom. Il. 1.37-42, the priest Chryses offers a famous prayer to the god Apollo:

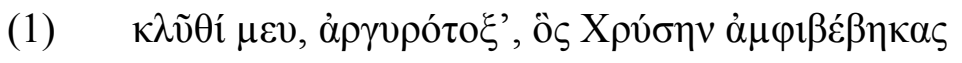

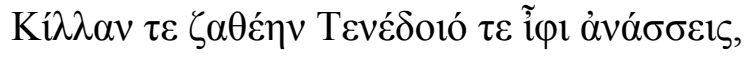




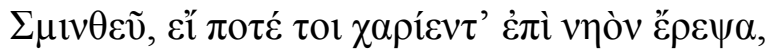

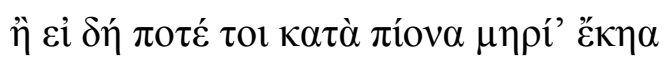

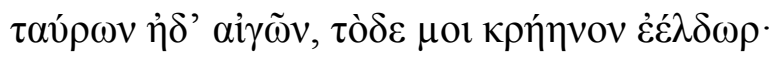

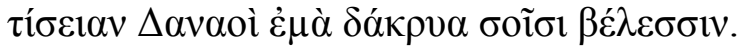

Hear me, Apollo of the silver bow, you who guard Chryse,

and most sacred Cilla and rule over Tenedos with your might, destroyer of mice, if ever I covered a charming temple with a roof for you, or if I ever burnt fat thighs for you

of bulls or of goats, then fulfill for me this wish:

may the Danaans pay for my tears through your arrows.

A significant characteristic of this prayer is the link which Chryses makes between his past favours towards Apollo and the hope/expectation that his wish will be fulfilled. But this hardly surprises us. In Greek literary texts between Homer and the end of the classical period, religious communication was often about the exchange of goods and favours between humans and the divine world. Prayers, sacrifices, but also hymns of praise, were gifts to the divinities, but they were not intended as one-way traffic. Characters expressed the hope that in return for their gift they would receive the favour they had asked for in a prayer. When a wish had been granted, there were different ways of thanking the gods and perhaps asking for another favour. In any case, prayers, hymns and sacrifices in literature seem to have been framed as if they were part of a two-sided relationship between mortals and divinities, a relationship that was based upon mutual exchange. In this paper I will discuss one aspect of this notion of reciprocity between humans and gods: cases in which humans are disappointed in their reciprocal relationship with gods.

Until fifteen years ago, the role of reciprocity in the Greek conceptualisation of religion was 'neglected' or 'undervalued' (Parker 1998, 105). However, various recent monographs and smaller studies assert that the mechanism of reciprocity is 
fundamental to the theological underpinnings of Greek popular religion. ${ }^{1}$ For example, Simon Pulleyn, in his influential study Prayer in Greek Religion (1997), explored the structure of prayers in Greek literature. Recognizing a do-ut-des 'I give, so that you will give' format in many prayers, Pulleyn also discussed a number of variations on this type. In literary texts, characters argue that gods should grant them a wish, because they have offered things to them in the past (da-quia-dedi), because the god has (not) granted a wish before (da-quia-(non)-dedisti) or so that they will (be able to) offer in the future, etc (da-quia-dabo). ${ }^{2}$ Pulleyn's categorization of requests and prayers shows how strongly particular requests to gods were framed as being grounded in a long-term reciprocal relationship between humans and the immortals.

Let us explore Chryses' prayer in Il. $1.37-42$ quoted as (1) above in a bit more detail. This passage is an example of the structure that appels to the notion of divine reciprocity perhaps most urgently: da-quia-dedi. ${ }^{3}$ Note that the structure is strictly speaking not: 'you should give, because of my previous offerings to you'. Instead, Chryses entreats Apollo to fulfil his wish, if ever ( $\varepsilon$ í $\pi \circ \tau \varepsilon, 40$ ) he built a temple or gave the god any pleasing gifts (40-41). This non-committal way of phrasing the request seems intended to transfer the interpretation of past exchanges to the god. Chryses seems to say: 'I am not sure whether you will take my previous gifts seriously, but if you do, you might consider doing something for me in return.' In other words, it is up to Apollo to decide whether the first human turn in the reciprocal relationship 'counts', if not, the conditional clause in the request serves to give the god a way out. Chryses' strategy relates to the nature of the reciprocal bond between humans and gods. Many scholars have pointed out that this relationship

\footnotetext{
${ }^{1}$ The central thesis in Pulleyn 1997 is the importance of $\chi \alpha$ ós in Greek prayer. In Yunis 1988, 50-58 reciprocity is taken to be one of the three fundamental religious beliefs of the Athenians, next to the ${ }^{2}$ Examples: da-quia-dedi: e.g. A. Th. 174-181; da-quia-dabo: e.g. A. Ch. 246-263, E. El. 805-808, S. OT 895-903; da-quia-dedisti: e.g. Hom. Il. 1.450-456 and da-quia-non-dedisti: e.g. Hom. Od. 6.323327. It has been objected that the absence of evidence in non-literary sources suggests that this is a purely literary motif (West 1997, 273). However, I follow Pulleyn 1997, 2-3 and Parker 1998, 107 in thinking that in these cases literary sources may be seen as a model for (or are at least not completely alien to) theological views in the polis. The notion of reciprocity is so widespread that it must somehow reflect the Greek mentality.

${ }^{3}$ Pulleyn 1997, 16-38 emphasizes that this structure is unique to Greek religion and does not occur in religions of the Near-East, but West 1997, 273-274 quotes literary passages from oriental texts that prove the opposite.
} 
should not be characterized as a 'commercial contract', but rather as a bond of reciprocal $\chi \alpha$ á $\varsigma$, characterized by the voluntary exchange of gifts between the two partners. ${ }^{4}$ Obviously such a relationship lends itself to slightly more indirect ways of presenting a request, as Chryses does. However, though Chryses expresses himself carefully, his underlying mindset seems clear. Chryses seems to think that humans can somehow make a claim to counter-favours from divinities and that one good turn of mortals deserves another from the gods. ${ }^{5}$

A significant parallel brought up by Pulleyn is the similarity between these prayers to gods and requests to other humans in reciprocal relationships: many prayers to gods have the same structure and vocabulary as, for example, requests in the institution of $\xi \varepsilon v i ́ \alpha$. For example, in Hom. Od. 3.98-101, Telemachus makes a request to Nestor:

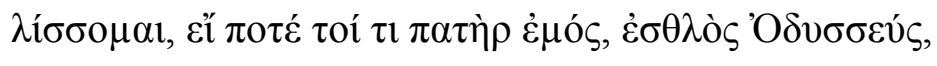

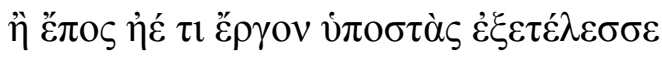

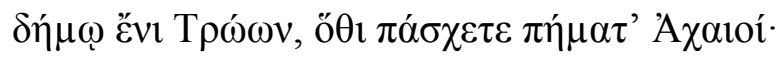

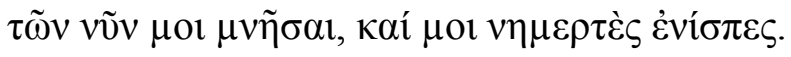

I beg you, if ever my father, noble Odysseus

having promised word or deed fulfilled that promise

in the land of the Trojans, where you Achaeans suffered so,

do now remember these things on behalf of me, and tell me sure truth.

Comparing this request with Hom. Il. 1.37-42 in (1) we can see the clear similarity in the way both arguments are delivered. The el $\pi$ o $\tau \varepsilon$ clause starting many prayers to

\footnotetext{
${ }^{4}$ The material terms in which the notion of reciprocity in Greek religion has been discussed above ('one good turn deserves another', do-ut-des) may give the - wrong - impression that Greeks conceived of the reciprocity between themselves and their gods as a 'contractual' bond. As has often been observed, this view is an oversimplification; in Pulleyn's words it is "to misunderstand the whole nature of reciprocity in Greece" $(1997,12)$. Rather, texts represent the idea that, by giving gifts to

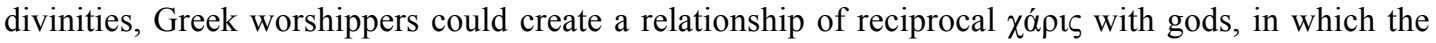
gods might grant them in return the wishes they asked for. On religion as a relationship of reciprocal

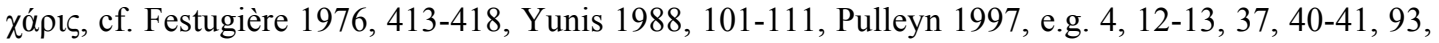

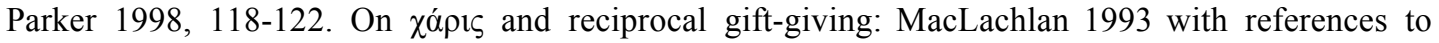
previous work, Saintillan 1996, Van Berkel 2013, 55-102.

${ }^{5}$ Similar cases are Hom. Od. 4.762-766, 17.238-246.
} 
gods in Homer precisely mirrors the phrases that are sometimes used in requests in $\xi \varepsilon v i ́ \alpha$ relationships. ${ }^{6}$ This likeness between prayers to gods and requests to guestfriends implies that, in prayers, in a way the inequality in the relationship to gods is suppressed and that humans saw their dealings with the divine as variants of their dealings with other mortals.

Moreover, the idea that gods should reciprocate favours apparently seems in the representation of the Greeks - to have been shared by the gods themselves. The collective cultural knowledge contained many examples of this idea: in numerous passages in the Homeric epics, for example, Olympian gods are reluctant to let mortals perish who have given them many offerings. In a well-known passage, Zeus considers saving Hector, who is his pínos and has brought him many sacrifices. $^{7}$ Although the text does not explicitly make a causal link between Hector's gifts and Zeus' unwillingness to let Hector die, such a connection is most definitely implied, and it would a very small step for a Greek reader to make the association. Such cases take the notion of reciprocity in Greek religion one step further than Hom. Il. 1.37-42, cited in (1) above. Mortal characters in the Iliad were not the only ones who viewed their relationship with the divine world as one in which gods should reciprocate favours. In the literary representation of Greek religion in this passage, not only humans, but also the gods themselves have the notion of reciprocity at the back of their minds.

Finally, note that a divine preoccupation with reciprocity is in line with another aspect of the Greek conceptualisation of the divine world. Greek gods showed a very special interest in reciprocal relationships among mortals, such as the dealings between parents and children, between guests and hosts, or towards suppliants. ${ }^{8}$ The functioning of reciprocity, or alternatively, transgressions of proper

\footnotetext{
${ }^{6}$ Pulleyn 1997, 28-29. A case similar to Hom. Od. 3.98-101 is Od. 4.328-331. Cf. Parker 1998, 120, and Yunis 1988, 104 n. 6 referring to Finley 1954.

${ }^{7}$ This is Hom. Il. 22.168-176; compare Il. 24.32-38, 24.66-70, 24.425-428. A similar train of divine thought is found in $O d .1 .59-79$.

${ }^{8}$ The relationship between parents and children is a prototypical case of a very long-term, mutual bond; with regard to $\xi \varepsilon v i ́ \alpha$, the relationship between guest and host was a long-term mutual bond that carried over generations. Concerning $\xi \varepsilon v i ́ \alpha$ and supplication, even if neither of the partners in such an established relationship nor their children ever met again, guestfriendship and supplication were reciprocal on the level of the institution. A man who received a guest or a suppliant on one occasion could count on the same treatment when he was in the dependent role on an other occasion. On $\xi \varepsilon v i ́ \alpha$
} 
conduct in especially these types of relationships were often evaluated by means of

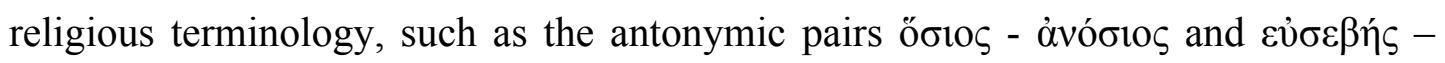
$\alpha \sigma \varepsilon \beta \eta ́$ s. ${ }^{9}$ Desirable religious behaviour, or 'piety' often meant 'acting in an ethically right way towards other humans': to please the gods, humans must especially honour special reciprocal relationships among themselves.

The prominence of reciprocity in Greek religion invites a logical next question. Were Greek gods, as they were presented by their believers, held to the same standards of reciprocity that they themselves imposed on humans? In other words: given that, in Greek literature, characters conceptualised their relationship

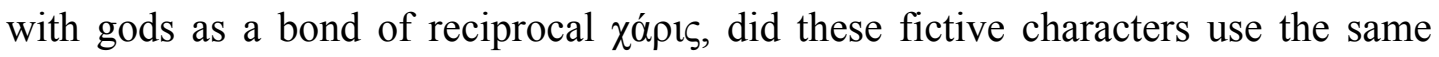
conceptual frame in talking about frustrated expectations of divine reciprocity? Or to put it yet differently: when gods did not give in return what had been hoped for, was such disappointment ever constructed as a case of dysfunctional reciprocity?

Even without examining any of the Greek literature at all, there are at least three reasons to assume that cases, in which disappointment in gods is framed in terms of a lack of reciprocity, will be uncommon. Before turning to the data, we should address these expectations and show that the question is nevertheless valid. First of all, the perceived asymmetry in power between humans and gods raises the expectation that gods were not readily reprimanded - in reality or in literature when they did not give in return. This expectation is not entirely borne out by our sources, because there is a considerable number of passages in Greek literature where humans express anger against the gods, ${ }^{10}$ and sometimes also state that if the god will not help, he is unwise ${ }^{11}$ or not interested in humans, not powerful or not an existing god at all. ${ }^{12}$ Still, such cases are relatively restricted. What we find much more often are narratives emphasizing the positive relationship between mortals and

\footnotetext{
as a form of ritualised friendship, encompassing a reciprocal bond of exchange of goods and favours between individuals cf. Herman 1987, 10 and Mitchell 1997, 12-14, 16-18.

${ }^{9}$ To give just two examples, in E. Cyc. 285-312, 347-349, Odysseus urges the Cyclops Polyphemus to

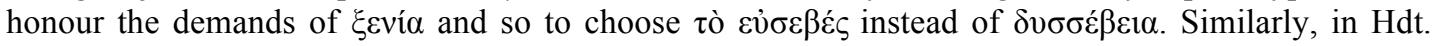
2.114-115, Paris' conduct towards his host Menelaus (i.e. the abduction of Helen) is discussed as an

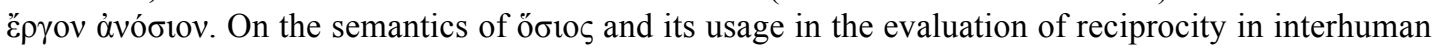
relationships cf. Blok 2011, Blok forthc., Peels 2014.

${ }^{10}$ e.g. Hom. Il. 3.365-368, 12.163-172, 21.272-283, E. Ion 252-254, 436-451, Hel. 1097-1106.

11 e.g. Thgn. 373-400, E. Ph. 84-87.

12 e.g. E. Cyc. 347-355, 606-607, Hec. 488-491.
} 
divinities, which makes sense: on a meta-level it was a much better strategy for a polis to promote the performance of this positive type of story, for such optimistic assertions praised gods, but at the same time they had a performative function. Works of art that celebrated the close-knit bond between humans and their gods advertised how well (certain groups of) Greeks were regarded by gods, and in that way Greeks promoted their own cause. ${ }^{13}$ Moreover, perhaps framing disappointment in a god in terms of frustrated reciprocity was especially infelicitous. One would for example run the risk that the god gave one a taste of one's own medicine and turn the broken chain of positive reciprocity into a nexus of negative $\chi \alpha$ ós: tit for tat.

Apart from an asymmetry in power, there is a second reason why it is a priori unlikely that the Greeks would complain about failed reciprocity when their gods were concerned. It was also assumed that there was an asymmetry in knowledge between Greeks and their divinities. The Greek worshipper was definitely not so simple-minded as to conceive of his interactions with the god as a straightforward one-to-one relationship in which one good turn deserved another. From many sources, starting with the Homeric epic, we can tell that the believer suspected that theodicy should be really viewed on the larger scale of the divine master plan, knowledge of which is unavailable to humans; ${ }^{14}$ that different types of supernatural forces had a share in the development of events, ${ }^{15}$ and that gods might at times have conflicting interests between them. ${ }^{16}$ For example, in Euripides' Hippolytus (1327-1334) the goddess Artemis states that she cannot help Hippolytus because she cannot oppose the will of Aphrodite. Apparently, the Greeks reflected on the problem that their many gods might at times want different things. We can see this story as an expression of those reflections. ${ }^{17}$ Humans realized that their limited

\footnotetext{
${ }^{13}$ This point was suggested to me by C. Williamson (personal communication).

${ }^{14}$ On theodicy in Greek religion see the seminal work of Lloyd-Jones 1971, for a recent discussion Versnel 2011, 151-237.

${ }^{15}$ A recent discussion of the difficult question of the relation between $\mu$ oi $\rho \alpha$ and the gods in literature is found in Versnel 2011, 163-175. On the perception of mortals of this relation, see e.g. A. A. 661666, E. Cyc. 606-607, E. Hec. 488-491, E. HF 1393, E. Heracl. 934-935, S. Ph. 1316-1320, Hdt. 1.91. ${ }^{16}$ Cf. P1. Euthphr. 7b-8b.

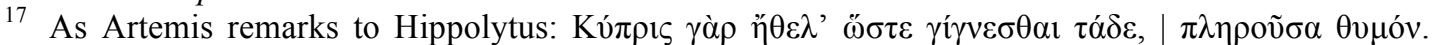

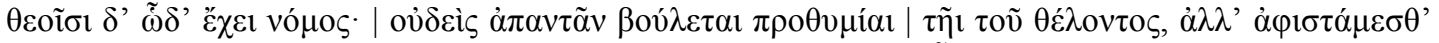

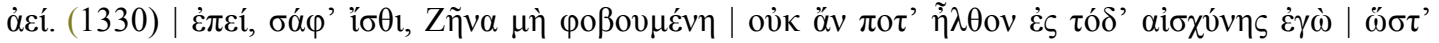

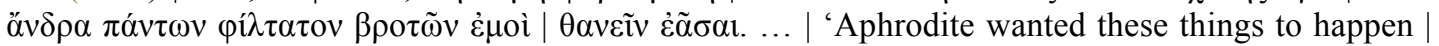
glutting her rage. Among the gods the custom is this: | no god wants to oppose the will $\mid$ of another,
} 
perspectives made it impossible always to assess why a particular request was not granted.

Finally, the Greeks probably perceived of a third asymmetry between mortals and gods: the Greeks knew that the gifts they presented to gods (animals, wine, other small commodities) could never equal what gods gave to men (health, property, life itself), by far. ${ }^{18}$ So, since gods have already done their part in the mutual relationship, a Greek might think it absurd for a human to complain if a particular favour was not granted.

In any case, we can see there was a definite tension in the theology underlying religious expressions. The notion of reciprocity appeared prominently in the Greek conceptualisation of the bond between humans and the divine, but at the same time, because of the perceived asymmetries between gods and men - in power, knowledge and contribution to the relationship - it was apparently impossible for the Greeks to follow the idea through to its logical consequences, i.e. to complain about cases in which gods had not given in return. Both Yunis (1988) and Parker (1998) have commented on this inherent tension. These scholars see the use of the notion of reciprocity as an attempt to get closer to the gods; as a way for the Greeks of allowing themselves to believe that the gods are not completely 'unintelligible', 'unpredictable', 'unreachable'. Greek religion contained - to borrow Coleridge's expression, commonly used to describe the effects of narrative - a 'willing suspension of disbelief', as it were, that made this conceptualization work, despite its inherent tensions. ${ }^{19}$ In spite of the asymmetries discussed above, there is a level on which the fiction was created that there was a more or less straightforward reciprocal

but we always stand aside. (1330) | For be well assured of it, if it were not that I feared Zeus $\mid$ I for one would never have reached such a shameful situation $\mid$ as to allow the death of a man who is dearest of all mortals | to me. ...' Note that, as in the story of Zeus and Hector, the implications of $\varphi i \lambda i \alpha^{\alpha}$ ( $\varphi$ í $\tau \alpha \tau$ ov, 1333) are part of the divinity's deliberations.

${ }^{18}$ Festugière 1976, 418, Parker 1998, 122. For a more general anthropological approach to the incommensurable, unpayable debt that humans owe to gods, cf. Godulier 1996, 44-47, 258-259, 269.

${ }^{19}$ Parker 1998, 120: "The language of kharis sustains, indeed creates, the fiction that the relation between human and god can be assimilated to that between human beings and so brought within a comprehensible pattern. The commercial view of kharis treats as a device to manipulate the gods what is more fundamentally a means of gaining access to them, of reaching the unreachable", and (124125): "The job of kharis, of gift and counter-gift, was to veil these differences, however temporarily and partially, to pretend that the gap between man and god was not too wide to be bridged, and to found that social relationship without which the gods and the world would be completely beyond our grasp" [underlining mine]. Cf. Yunis 1988, 53. 
exchange between humans and gods. Therefore, I think it is useful to ask how far this conceptualisation is taken, and to see if and under what circumstances did humans express discontent at divine reciprocity.

This question has not received the attention it deserves in the scholarly literature. There are scholars who discuss cases of Greeks criticizing gods. ${ }^{20}$ But these authors do not distinguish a separate category of complaints about frustrated expectations of reciprocity (because that is not their research focus). In an excellent discussion of the idea of reciprocity in Greek religion, Robert Parker gives cases where, more specifically, humans are disappointed in the mutual exchange with gods. ${ }^{21}$ For example, there is the story of Croesus, king of Lydia, on the pyre, as related in Herodotus' Histories 1.86ff. Having been defeated by the Persian king Cyrus, Croesus was placed on a burning pyre; he was saved, in the nick of time, by the intervention of Apollo; then he was granted a wish, as a reward for a piece of good advice he had given to Cyrus. Croesus had been a benefactor to Delphi on an unprecedented scale. ${ }^{22}$ Even so, the oracle had wrongly encouraged him (or so Croesus thinks) to march against the Persians; and Croesus had been defeated and had lost everything. Therefore, Croesus' wish was to ask the god of the Greeks, whom he had honoured (verb: $\tau \mu \alpha \dot{\alpha} \omega)^{23}$ most of all, whether it was the way (vó $\mu$ o $)$

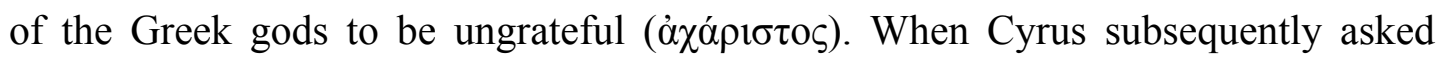
Croesus what motivated his wish, he particularly ( $\mu \alpha \dot{\lambda} \iota \sigma \tau \alpha)$ recalled the offerings he had made to the god. As we can see, Croesus' criticism of Apollo is based precisely

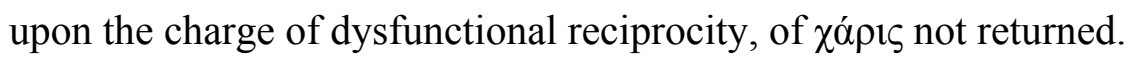

But although it is clear from the scholarship that these cases exist, the status of such passages does not emerge from previous discussions. Did such complaints occur often? How did Croesus' question sound to a Greek of the fifth century? Did they consider it a hubristic statement of a foreign king? Or rather as a rightful concern of Croesus? And what does the fact that Croesus was himself in the wrong

\footnotetext{
${ }^{20}$ Schadewaldt 1926, 118-122, 128-138, Dale 1969, Labarbe 1980, Versnel 1981, 37-42.

${ }^{21}$ Parker 1998, 114-116.

${ }^{22}$ A description of his many gifts and offerings is presented in Hdt. 1.50-52.

${ }^{23}$ This and following quotes from Hdt. 1.90.
} 
in his interpretation of the oracles contribute to that view? ${ }^{24}$ These concerns are relevant to our reading of the passage and the characterization of Croesus in Herodotus as a whole. However, since there is no clear view of when, where and how often such complaints occur, these questions have been difficult to answer. ${ }^{25} \mathrm{I}$ wish to address these issues in this paper.

I will argue that explicit disappointment in divine reciprocity occurs almost exclusively under 'special circumstances'. ${ }^{26}$ It is typically not expressed by 'normal' and pious Greek characters referring to the normal practise of Greek worship. By contrast, this type of reproach is presented by characters who do not fall under that category for various reasons, for example because they are not Greek; ${ }^{27}$ or dead; ${ }^{28}$ by characters whom the author wishes to portray as having abnormal views, ${ }^{29}$ or, the most common type - by characters who actually have a different type of reciprocal relationship with a god, based on a mythological family bond..$^{30}$ Moreover, almost all complaints turn out to be unfounded: the god is justified after all. ${ }^{31}$ In short, I want to show that passages in which gods are confronted with their dysfunctional reciprocal behaviour are not only highly uncommon. This distribution and nature of complaints shows that reproaching gods about disappointed reciprocity was only acceptable

\footnotetext{
${ }^{24}$ Croesus' reproach is ungrounded and based upon a misjudgment of his own situation. Croesus had asked the oracle of Delphi whether or not he should march against the Persians (1.53). The oracle had answered that he would destroy a great empire if he did (1.53) and Croesus had wrongly interpreted this message as encouragement (1.54). The god had in fact not deceived him, but by misunderstanding the oracle, Croesus had caused the downfall of his empire himself. Finally, the god is vindicated also because Apollo had postponed the - fated - sack of Sardis for three years (1.91). In reality, the god had shown as much $\chi$ ópıৎ̧ to Croesus as he could.

${ }^{25}$ For example, Pelling 2006, 161 with n. 73 seems to wonder how normal Croesus' complaint is, when characterizing it as "un-Greek", but also adducing parallels and stating it is "admittedly not so irregular". McDevitt and Cairns consider the similar question posed by Croesus in Bacchylides' third

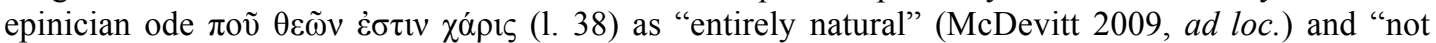
unparalleled ..., indeed it is a reasonable question to ask in the context of a religion which operates on the principles of do ut des and charis" (Cairns 2010, ad loc.).

${ }^{26}$ Note that my approach differs from that of Yunis 1988, who views all human complaints to gods as implicitly or explicitly expressing frustrated hopes of reciprocity. Yunis' viewpoint is valid, but what I want to see is where, and how, claims about disappointment in the mutual relationship with gods are made explicit. Therefore, I focus on those human complaints that in my eyes unambiguously target the reciprocal nature in the human-divine relationship.

${ }^{27}$ Hdt. 7.35, 1.90, Bacch. 3.37-39.

28 A. Eu. $106-109$.

${ }^{29}$ E. Hipp. $1363-1370$.

30 A. Supp. 168-175, S. Tr. 993-995, 1264-1271, E. HF 339-347, E. Heracl. 709-719 and E. Ion esp. 384-388, 905-922.

${ }^{31}$ This was already noted by Parker 1998, 115 for the sample he discussed.
} 
within the mythological frame of family-relationship with a god, but was a very unGreek thing to do otherwise.

First of all, disappointment in the reciprocal exchange with gods is articulated by characters who do not fall under the category of normal, pious Greeks for various reasons, e.g., because they are not Greek. We see this in Herodotus' Histories 7.35, which narrates the story of Xerxes bridging the Hellespont. Xerxes' first bridge had just been destroyed by a storm. The Persian king was not amused. He commanded that the Hellespont be whipped, while, as Herodotus tells us, the following

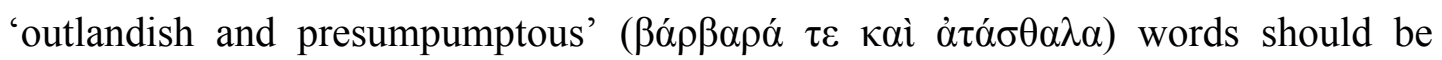
uttered:

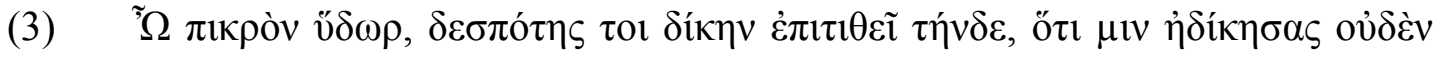

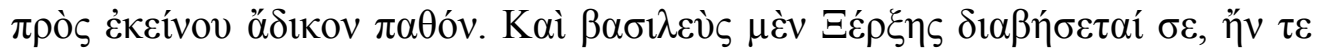

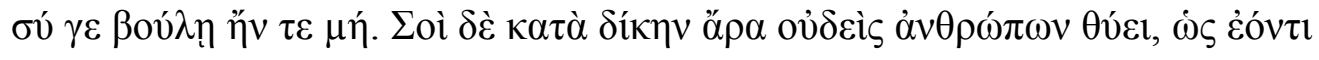

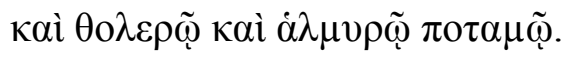

Bitter water, our master punishes you, because you did him injustice, while you did not suffer an injustice from his side. Xerxes the king will pass over you, whether you want it or not; it is natural that no human offers to you, for you are a foul and distasteful river.

As we see, Xerxes expresses his disappointment in terms of the reciprocal relationship between him and the water, whom he seems to consider a divinity. ${ }^{32}$ Xerxes' slaves point out how unfair the Hellespont's 'bad treatment' of Xerxes was, appealing to a negative version of the rules of reciprocal $\chi \alpha$ ópı, which may be summed up: 'if I did not harm you, you should not harm me'. Given the present state

\footnotetext{
${ }^{32}$ It is crucial to our analysis that we treat the passage as expressing the view that the Hellespont is a god. The fact that Xerxes treats the water like a sentient entity (to whom one may speak and upon

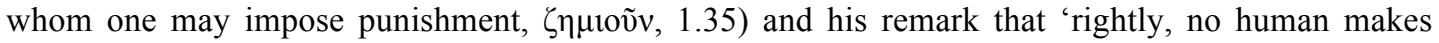
offerings to you' both suggest an underlying view that the Hellespont is indeed a god. Moreover, Xerxes does make sacrifices when he eventually crosses the Hellespont over his second bridge (Her. 7.54), throwing a cup of wine a golden bowl and a Persian sword into the sea. These actions can also be seen as an indication of the perceived divine status of the Hellespont. Versnel 1981, 39 seems to agree when he writes: "the best example of a god being punished is Xerxes' decision to have the Hellespont flogged and shackled". Cf. also Mikalson 2003, 45, 80-81.
} 
of affairs Xerxes gives the strait tit for tat - a due return for its malevolent actions. But Xerxes' words cannot be considered as representing 'normal' Greek piety. On the contrary, in this passage, we are given clear hints that the Persian ruler's character serves as a foil to desirable Greek religious behaviour: Herodotus describes

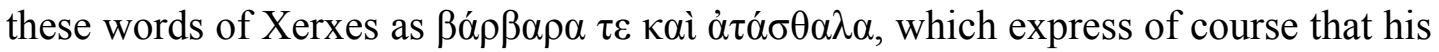
conduct is un-Greek and uncivilized. ${ }^{33}$ At the same time, this phraseology targets the

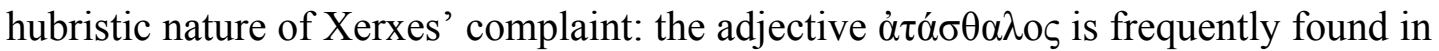
close connection with hybris words in archaic Greek poetry (Nagy 1979, 163, Fisher 1992, 155, Mikalson 2003, 47). Clearly, the expression of disappointment in divine reciprocity in this passage is part of Xerxes' presentation as a barbarian character, whose conduct is in all possible ways the opposite of how a Greek would behave towards the gods.

Another complaint is made by Clytemnestra in Aeschylus' Eumenides. Clytemnestra reproaches the Erinyes, who are sleeping instead of pursuing Orestes:

(4) $\tilde{\eta} \pi 0 \lambda \lambda \grave{\alpha} \mu \dot{\varepsilon} v \delta \grave{\eta} \tau \tilde{\omega} v \dot{\varepsilon} \mu \tilde{\omega} v \dot{\varepsilon} \lambda \varepsilon \dot{\xi} \xi \alpha \tau \varepsilon$,

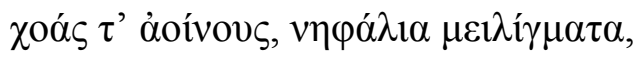

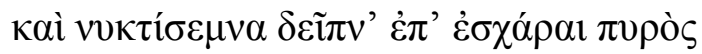

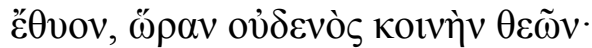

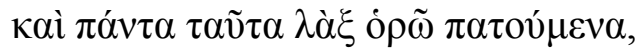

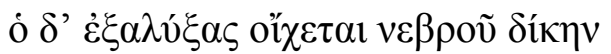

Truly you have licked up many of my offerings,

Drink-offerings without wine, sober propitiatory offerings,

And I have sacrificed banquets solemnized by night, on a hearth of fire,

At an hour not shared with any of the other gods.

And all of that I see trampled under foot,

But he [i.e. Orestes] has escaped and is gone, like a fawn.

\footnotetext{
${ }^{33}$ Note that the presentation of this event by Herodotus may not have been a correct interpretation of what happened. Kuhrt 2007 points out that the whipping of the Hellespont may have been part of religious ritual. For example, Boyce 1982, 116 interprets Xerxes' whipping of the Hellespont not as a hubristic punishment, but as a ritual, connected to the Iranian belief that seawater is sweet water contaminated by chaos; whipping the sea, then, is a way of taking out the forces of chaos.
} 
Clytemnestra addresses the failing reciprocity of these deities quite clearly, summing up all her offerings (106-109), and then complaining how she sees all of that 'trampled under foot' (110). But again, in this case the circumstances are different from those of an 'ordinary' Greek reproaching his god. Clytemnestra has been killed and appears in this play as a ghost. As a ghost, she is a chthonian power herself. Hence her relationship to the Eumenides is considerably different from that between living mortal and god. One may speculate that Clytemnestra would have made the same complaint when still alive. However, we do not have any example of the living Clytemnestra saying or thinking anything similar. Taking the evidence at face value, Clytemnestra's position vis-a-vis the gods she addresses at this point in this play is clearly not a 'standard' case.

The second circumstance under which disappointment in the reciprocal exchange with gods is expressed, is when this is done by a mortal who is portrayed as having quite abnormal views. We find such a case in Euripides' Hippolytus. Towards the end of this play, the eponymous protagonist cries out:

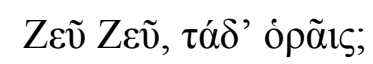

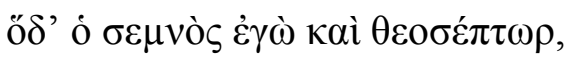

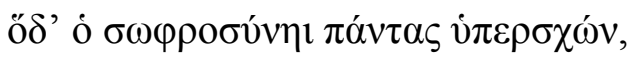

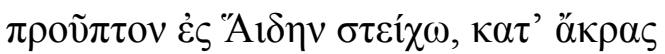

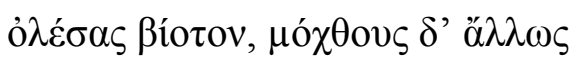

$\tau \tilde{\eta} \varsigma \varepsilon \dot{\sigma \varepsilon \varepsilon \beta i ́ \alpha \varsigma}$

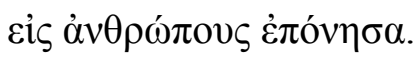

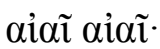

Zeus, Zeus do you see this?

This man, me, the reverend and god-fearing one,

the man who exceeds all in sophrosyne

I go to a clearly seen Hades, I have

lost my life utterly, in vain my labours

of piety 
towards men I have toiled.

$\mathrm{Ah} !$

The notion of 'piety towards men' seems to reflect a trait of Greek religious thought that was discussed above. In order to be pious towards the gods, one needed especially to respect relations with other humans. Furthermore, when Greek gods (should) look at something, this often involves that they also (should) act. In such contexts, the verb óóc $\omega$ is used in questions ('do you see this?') or an admonition ('look at this!') both with an illocutionary force 'do something about it'. ${ }^{34}$ In this case, too, it seems to me that we should read Hippolytus' question to Zeus as reflecting his despair and indignation. Apparently, Zeus is not doing anything, but it was all 'in vain' (a' $\lambda \lambda \omega \varsigma, 1367)$. Thus, Hippolytus seems to make an (implicit) complaint that is grounded in a bad 'treatment' from the gods in return for his piety.

It seems to me that the internal and external audience would have interpreted Hippolytus' reproach of the gods in these lines as part of this dramatic presentation of his character. As has been amply discussed by others, the oddness of Hippolytus' views are expressed throughout this play. ${ }^{35}$ Hippolytus clearly misses a realistic view of the world in general, and the right attitude to Greek polytheistic religiosity in particular. Among Hippolytus' flaws is, of course a lack of religious understanding that contrasts with his admirable and ardent devotion to Artemis. In this particular speech, almost every sentence underscores Hippolytus' idiosyncratic views. Hippolytus refers to himself as $\sigma \varepsilon \mu \nu$ ó (1364): this term means reverend, devoted to the gods, but also connotes self-importance or exaggerated self-respect. While positive when used for gods, the adjective is usually pejorative when applied to mortals. ${ }^{36}$ Furthermore, Hippolytus says he considers himself to surpass all others in $\sigma \omega \varphi \rho о \sigma v ́ v \eta$, but as Rademaker points out in his semantic study of this term, Hippolytus' view of it is entirely abnormal. ${ }^{37}$ Finally, in making the rather odd

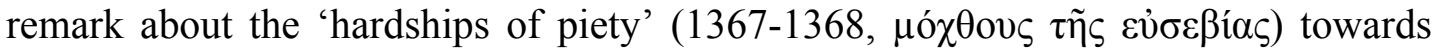

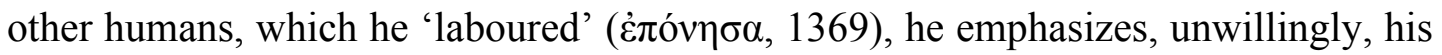

\footnotetext{
34 e.g. S. OC 278-279, A. Eu. 110, E. Cyc. 353.

${ }^{35}$ Cairns 1997, 51-53, Halleran 1995, 39, Barrett 1964.

${ }^{36}$ Cairns 1997, 72, E. Hipp. 93-94.

37 Rademaker 2005, 163-173.
} 
self-absorbedness (for apparently, to consider his fellow humans and treat them well was quite a strain to him). ${ }^{38}$ The irony of the passage does not just lie in the fact that Hippolytus fails to see he has brought destruction upon himself, by disobeying the goddess of sexuality. The fact that Hippolytus makes this type of complaint at all contributes to the thick layer of dramatic irony in his speech.

The third circumstance under which we find the expression of frustrated hopes of reciprocity by gods, is when the god in question is actually in a special kind of long-term reciprocal relationship with a mortal, which occurs when a god has parented a mortal son. The speaker of the complaint is either this son himself, or his mother, or the foster parent of a son co-parented by a god. Being a parent, the god has created a bond not only with his offspring and the mother of his child, but also with other core family members. When gods have entered into such a bond, 'normal' Greek characters are portrayed as feeling entitled to criticise them on the grounds of failed reciprocity. Moreover, in some of these cases, the suggestion is created that the god is (like) a fellow human. This presentation of the mortal's connection to the relevant god facilitates the complaint. ${ }^{39}$ Thus, notably, these cases treat an different type of reciprocity than that based upon offering and gift giving to gods. ${ }^{40}$

A famous example of such a situation is found in Euripides' Ion (esp. 859922). As is related in the prologue of this play, Creusa was raped by Apollo in a cave

\footnotetext{
${ }^{38}$ The word $\theta \varepsilon o \sigma \varepsilon ́ \pi \tau \omega \rho$ (1364), god-fearing, is (apparently) no ordinary adjective either, for the word only occurs here.

${ }^{39}$ Parker 1998, 114-115 gives a few examples where complaints arise from the relationship between a god and his mortal son or lover or are uttered by a non-Greek. The new steps I take are a) I do not see these circumstances as coincidential characteristics of some passages; and b) I do not consider them examples of cases where a disappointment in the regular reciprocal relationship with gods is expressed.

${ }^{40}$ In my view, the charis in gift-giving between gods and humans and the charis in family relationships are different cases, because they fall under different 'frames'. Such cultural scenarios or scripts each come with their own sets of logic, associations and expectations. The relationship between parents and children is the prototypical example of a very clear long-term reciprocal bond. Parents should feed, raise and protect their children teach them a $\tau \dot{\varepsilon} \chi v \eta$, and preferably leave them an profitable oikos and a good reputation to enjoy. The grown-up child is expected to pay back its parents' long-term investment by caring for them, burying them properly and then continuing to honour them with religious rites. These things were to some extent even defined in the law. Children's obligation to

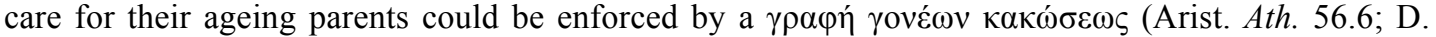
24.103-105), while children whose parents had hired them out for prostitution or had failed to teach them a profession were exempt from this obligation (Aeschin. 1.13, Plu. Sol. 12). This relation is rather different from reciprocal gift-giving between humans and god as chanelled through prayer and sacrifice. That exchange is characterized by vagueness and indeterminability with respect to value and reasonable expectations of gift and countergift (cf. main text).
} 
at an earlier point, had become pregnant and given birth and had left the child to die. But Apollo had asked Hermes to fetch the child from Athens and bring it to the

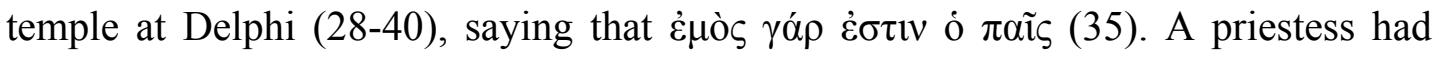
found him and raised him, not knowing that Apollo was his father. Creusa married Xuthus, but their marriage remained childless, which is why this couple travelled to the oracle of Delphi years later. Throughout the play, Creusa is very bitter about Apollo, (wrongly) supposing that this god had not looked after his child and that it is now dead. ${ }^{41}$ In Creusa's famous monody (859-922) in the play, after she has heard that Xuthus has a son of his own, she explicitly casts her complaints towards the god

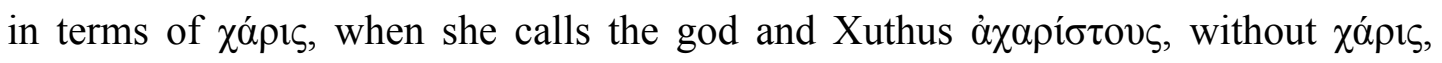

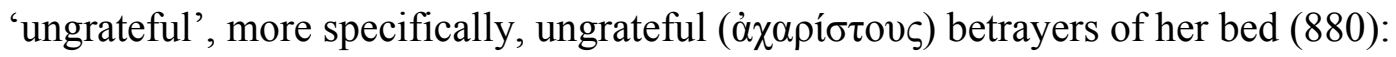

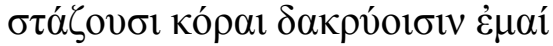

$$
\begin{aligned}
& \psi v \chi \eta ̀ ~ \delta ' \alpha \lambda \lambda \gamma \varepsilon \tilde{\imath} \kappa \alpha \kappa o \beta о v \lambda \eta \theta \varepsilon \tilde{\sigma}{ }^{\prime}
\end{aligned}
$$

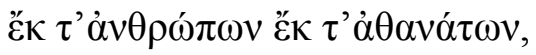

$$
\begin{aligned}
& \text { ỡ } \grave{\alpha} \pi \mathrm{o} \delta \varepsilon \hat{\xi} \xi \omega
\end{aligned}
$$

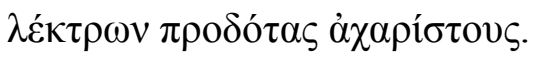

$$
\begin{aligned}
& \text { My eyes are dripping with tears } \\
& \text { and my soul is in pain, because I was so ill-advised } \\
& \text { by men and immortals alike, } \\
& \text { whom I shall show } \\
& \text { to be ungrateful betrayers of my bed. }
\end{aligned}
$$

By having sexual intercourse with Xuthus and Apollo, and by giving birth to

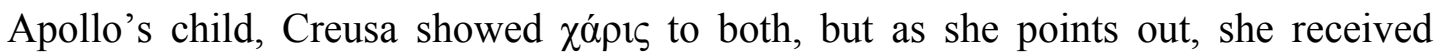
nothing in return. Note that Creusa mentions the way she was treated by men (i.e. Xuthus) and the way she was treated by gods (i.e. Apollo) in a close conjunction

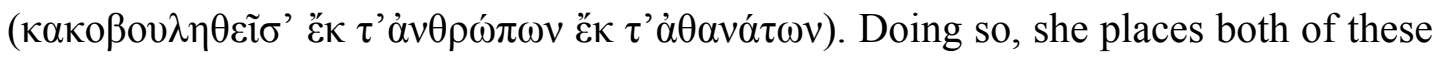

\footnotetext{
${ }^{41}$ In 247-54 she says in general terms that humans are being destroyed by the injustices of their masters (the gods). In 384-389, she pretends Apollo raped a friend of hers, not herself, and accuses the god that he is not díkalos because he did not save his son. In 436-451, Ion is angry with Apollo because he 'secretly breeds children, then leaves them to die'.
} 
relationships on the same level, enabling her to judge both Xuthus and Apollo in the context of the same type of relationship to herself.

But things are even worse than that, as she explains in another accusation of Apollo in her monody in 912-915:

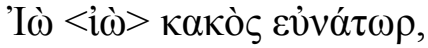

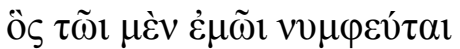

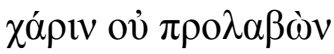

$$
\begin{aligned}
& \pi \alpha i ̃ \delta \text { ' }
\end{aligned}
$$

Oh, oh, worthless lover

who settle a son at home for my husband,

although you received no favour (from him) beforehand.

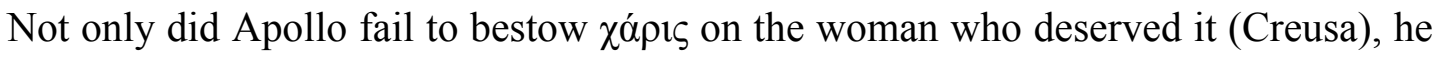
he gave her husband a child (913-915), and so did do Xuthus a huge favour, although

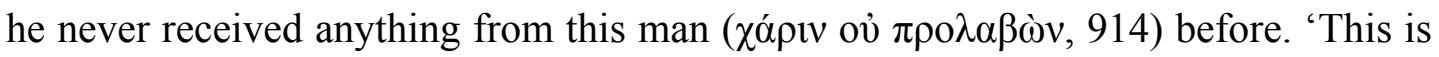

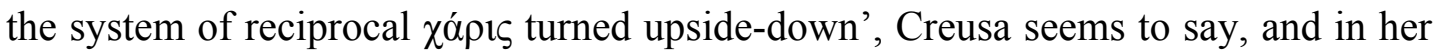
present state of knowledge, she is right to be upset. ${ }^{42}$

In a second passage (Euripides' Children of Heracles 709-719), the theme of thwarted expectations of reciprocal $\chi \alpha \dot{\rho} \rho \varsigma \varsigma$ by a parent-god is treated particularly effectively, though more implicitly. In Children of Heracles, king Eurystheus of Argos is in pursuit of Heracles' children, whom he wants to kill. They flee under the protection of Iolaus (Heracles' nephew) and Alcmene. At some point, Iolaus decides to go out and fight, assuring Alcmene that Zeus will be concerned about her and the grandchildren. Alcmene is sceptical:

\footnotetext{
${ }^{42}$ Our understanding of the communicative value of all of the reproaches in Ion discussed above has benefited from Zacharia's analysis of this play. As Zacharia 2003, 88-96 points out, drawing on earlier work notably by LaRue 1963, Creusa's monody is a skilful reversal of the traditional hymn both in content and form. A hymn often contained a part intended to persuade the god to grant the suppliant the requested favour (the hypomnesis), sometimes by means of a do-ut-des argument (as discussed in section 1 above). Creusa's reproaches to Apollo feature in the part of the 'hymn' where normally the hypomnesis would be, and as we can see, she skilfully inverts two types of the do-ut-des argument. Instead of telling Apollo that 'she gives, because then he will give' or that 'he should give, because she has given' she accuses that 'he gave nothing even though she did'.
} 


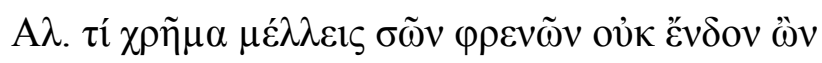

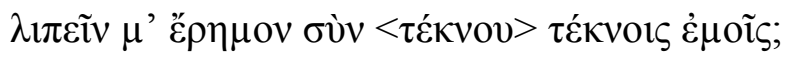

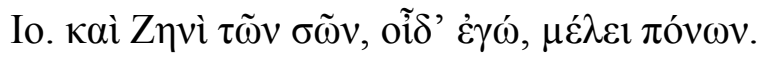

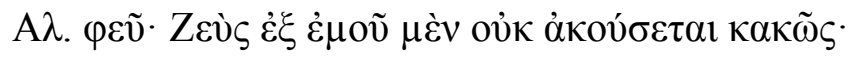

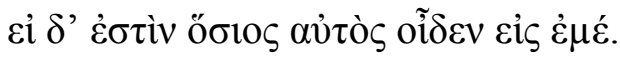

Alcm. Why are you planning to leave me deserted, with my grandchildren, are you out of your mind?

Ion. And Zeus will be concerned about your troubles, I know that.

Alc. Pheu! Zeus will hear no angry words from me.

But he knows himself if he is loyal (ő

I interpret (with Wilkins 1993 and Allan 2001, ad loc.) Alcmene's complaint in 718719 as referring to Zeus' fatherhood of Heracles. But what exactly does Alcmene

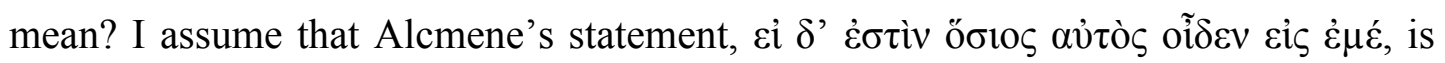
meant as an ironical statement: Zeus is not ő $\sigma 10 \varsigma .{ }^{43}$ The evaluative adjective öбıৎ 'pious', 'just', 'pleasing to the gods' is particularly difficult to translate here, because this term is normally used for humans. Since 'piety' is a behavioural norm that gods set for humans, it is extremely unusual to use this term for a god: this paradoxical application of the term ö $\sigma ı \varsigma$ to a god hardly occurs anywhere else. ${ }^{44}$ Because this usage is so rare, the audience of this tragedy would have perceived it as highly

\footnotetext{
${ }^{43}$ Such irony is understandable given all the hardships Alcmene has had to bear. Concentrating on the period after Heracles' death alone (which this play narrates), she has been pursued and threatened to death by Eurystheus, fleeing from city to city and denied everywhere. Now that she has finally been accepted at Athens, she has already endured the death of one of Heracles' daughters and at this specific point in the play there is an undecided war between Argos and Athens going on, in which the only other adult in Alcmene party, Iolaus, is determined to join, old and infirm as he is.

${ }^{44}$ Out of all attestations ö $\sigma ı \varsigma \varsigma$ and cognates in archaic in classical literature, the term is used only on 7 occassions in application to a god: Pi. P. 36, h.Merc. 129, 173, 470, E. Heracl. 719, E. Or. 595 and E. Alc. 10. For a analysis of these attestations as exceptional cases with an (intended) effect, cf. Peels 2014, 143-161.
} 
marked. ${ }^{45}$ What is the effect of that? This question has not received an answer in the scholarship. In my view, the paradoxical usage of ö $\sigma$ to for a god brings Zeus down to the level of a human, who is more easily reprimanded than a god. This passage confirms the pattern established above: humans take the liberty to judge the gods for their inadequate reciprocity, especially when gods are parents of mortal children and thus have entered into a particularly intimate mutual relationship with humans. In this case, Alcmene also facilitates her criticism of the god by treating Zeus as if he were a mortal.

Moreover, by choosing this adjective, Alcmene evokes a range of connotations attached to it. We have discussed above that long-term reciprocal relationships among humans, such as the bond between parents and child or between guest and host, are often evaluated by means of religious adjectives, like $\varepsilon v ̉ \sigma \varepsilon \beta \eta ́ \varsigma$ and ö $\sigma$ tos. Moreover, the evaluation of these relationships constitutes an important share

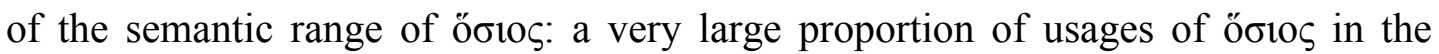
classical period actually refers to upholding these long-term human reciprocal relationships (prototypically, parents and children, guest and host, suppliant and protector). ${ }^{46}$ If Alcmene wished to underscore the close mutual relationship Zeus entered into with a human when he slept with Alcmene and conceived a son, this term is highly appropriate. By selecting this particular evaluative term, Alcmene activates the frame of loyalty in long-term mutual bonds among humans and thus places the relationship she and Heracles have with Zeus within that frame. ${ }^{47}$

Alcmene's highly unusual, compact utterance allows her to target the issue of this special type of reciprocity between humans and gods perfectly well. It enables her to say: 'Zeus, by fathering our child, has brought himself down to a human level and he is now in a relationship of mutual obligation with me in which he should look

\footnotetext{
${ }^{45}$ Note that it is not surprising that the utterance occurs within a passage that is marked itself: the scene has been characterized as humorous or even parodic (Zuntz 1955, 29, Burnett 1976, 18 contra Wilkins 1993, ad loc., for further discussion cf. Allan 2001, 183-185), although this, in my view, does not make Alcmene's utterance any less serious.

${ }^{46}$ Cf. Peels 2014, 36-37.

${ }^{47}$ The interpretation of öఠı̋ as 'being loyal to family' here is also prepared by the previous lines, containing Iolaus' assertion that Zeus will be concerned about Alcmene's troubles and by the fact that the theme of obligation created by family ties runs throughout the play, starting in the prologue.
} 
after me and my child. He knows himself whether or not he is honouring this mutual bond between us (in other words, he is not). ${ }^{48}$

One trait of these cases not yet discussed is the fact that most of them are factually disproved by the situation in which they are uttered. That is, they are embedded in contexts in which it is - or soon becomes - clear to the internal and/or external audience that the reproach of a particular character is ungrounded. ${ }^{49}$ The limited perspective of mortals causes them to condemn gods, but other instances like the chorus, other characters, or the outcome of the plot - show us that the god was not negligent or 'ungrateful'. Although characters utter 'real complaints', on the level of the text as a whole, these passages actually serve to vindicate the gods. This characteristic confirms the pattern established above. Criticism about the gods' lack of reciprocity does not reflect 'ordinary' Greek religiosity; and when these reproaches occur, they turn out to be unfounded.

This paper started out with a question: do humans address divine ungratefulness explicitly? The answer is 'no', but note that it is a very conscious 'no'. It is not an agrument from silence: it is not the case that we just never see Greeks addressing this issue. The evidence shows us that the Greeks have thought about it and that they have appartently answered the question in the negative. Not only is human suspicion that gods are ungrateful usually wrong (mortals' limited perspectives apparently often prevent them from make such judgments correctly). Greeks consider it abnormal to utter such thoughts in the first place. The gods are not rebuked for their lack of reciprocity by 'normal' and pious Greek characters referring to the ordinary practise of Greek worship. Rather, such disappointment is expressed by characters who for one reason or another do not fall under this category: by non-

\footnotetext{
${ }^{48}$ Other examples in which mortals reproach divine family-members with a lack of reciprocity are E. HF 339-47, A. Supp. 168-75, S. Tr. 993-95 and 1264-1272.

${ }^{49}$ Croesus caused his own downfall by misinterpreting the oracle and Hippolytus brought his destruction upon himself due to his neglect of Aphrodite. The relevant gods, Apollo and Artemis respectively, showed them as much $\chi \alpha$ ós $\zeta$ as they could. Apollo turns out to be not the criminal Creusa supposed him to be in Ion either. He did look after the child and prepared the course of events in the play until the recognition scene of Ion and Creusa (1539-1545). Finally, though Xerxes proclaims confidently that he did not do the Hellespont any harm, in fact he did, for by crossing the Hellespont he crossed a natural boundary between Asia and Europe. This would have been obvious to the audience, who were familiar with Aeschylus' Persians, in which 'Xerxes' transgression of the inviolable boundaries set between Greek and Persian is clearly one of the fundamental conceptions of the tragedy' (Anderson 1972, 168, Winnington-Ingram 1973, 216).
} 
Greeks and the deceased, by characters whose ideas of piety are aberrant anyway, and by those mythological figures who are in a family-relationship with a god and address a different type of reciprocity in their complaint. All of these facts work together to confirm a positive theology, in which Greeks seemed to be confident about being rewarded for their gifts to the gods. Moreover, these passages, by showing the epistemic misjudgment or even epistemic arrogance (for example, in the case of Xerxes and Hippolytus) of mortals, seem to teach us a lesson in humility. But the human suffering in these passages is not cancelled out by the divine vindication. ${ }^{50}$ The 'positive theology' contains this presence of human suffering, and so qualifies the optimistic picture that has emerged to some extent. Any true underlying criticism of the gods is not that they are ungrateful, but that they let such suffering happen. ${ }^{51}$

\section{Bibliography}

Allan, W. 2001. The Children of Heracles. Euripides; with an Introduction, Translation and Commentary (Warminster)

Anderson, M. 1972. The Imagery of the Persians, G\&R 19, 166-174

Barrett, W.S. 1964. Hippolytos. Euripides. Edited with Introduction and Commentary (Oxford)

Blok, J.H. forthc. A Convenant Between Gods and Men: Hiera kai Hosia and the Greek Polis, in: Rapp, C. (ed.) City - Empire - Christendom: Changing Contexts of Power and Identity in Antiquity (Cambridge/ New York)

Blok, J.H. 2011. Politics and the Gods: Hosie and Athenian Law from Solon to

Lykourgos, in: Azoulay, V., Ismard, P. (eds.) Clisthène et Lycurgue d'Athènes: Autour du Politique Dans la Cité Classique (Paris), 233-254

Boyce, M. 1982. A History of Zoroastrianism. II: Under the Achaemenians (Leiden) Bremer, J.M. 1998. The Reciprocity of Giving and Thanksgiving in Greek Worship, in: Gill, C., Postlethwaite, N., Seaford, R. (eds.) Reciprocity in Ancient Greece

\footnotetext{
${ }^{50}$ Hippolytus and Heracles make these complaints when they are actually dying. Creusa spent many years of her life worrying about her firstborn child. The reality that Apollo has prepared a glorious future for her and her son all along cannot undo this.

${ }^{51}$ Much gratitude is owed to Professors Josine Blok, Ineke Sluiter, André Lardinois, Robin Osborne, Peter Funke and Vinciane Pirenne-Delforge, who read drafts of this article and gave useful comments.
} 
(Oxford), 127-139

Burnett, A. 1976. Tribe and City, Custom and Decree in Children of Heracles, CPh $71.1,4-26$

Cairns, D.L. 1997. The Meadow of Artemis and the Character of the Euripidean 'Hippolytus', QUCC New Series 57.3, 51-75

Cairns, D.L. 2010. Five Epinician Odes (3, 5, 9, 11, 13) / Bacchylides. Text, Introductory Essays and Interpretative Commentary (Cambridge)

Dale, A.M. 1969. Note on Euripides, Helena 1441-50, in: Dale, A.M. Collected papers (Cambridge), 180-184

Festugière, A.J. 1976. Av $\theta$ ' $\tilde{\omega} v$, la Formule 'en Échange de Quoi' dans la Prière Grecque Hellénistique, RSPh 60, 389-418

Finley, M. 1954. The World of Odysseus (New York)

Fisher, N.R.E. 1992. HYBRIS. A Study in the Values of Honour and Shame in Ancient Greece (Warminster)

Furley, W.D. 2007. Prayers and Hymns, in: Ogden, D. (ed.) A Companion to Greek religion (Malden/Oxford), 117-131

Godulier, M. 1996. L'Enigme du Don (Paris)

Halleran, M.R. 1995. Hippolytus / Euripides. With Introduction, Translation and Commentary (Warminster)

Herman, G. 1987. Ritualized Friendship and the Greek City (Cambridge)

Kuhrt, A. 2007. The Persian Empire. Vol. 1 (London)

Labarbe, J. 1980. La Prière Contestaire dans la Poésie Grecque, in: Limet, H., Ries, J. (eds.) L'Expérience de la Prière dans les Grandes Religions (Louvain), 137148

Lloyd-Jones, H. 1971. The Justice of Zeus (Berkeley and London)

MacLachlan, B. 1993. The Age of Grace: "Charis" in Early Greek Poetry (Princeton)

McDevitt, A.S. 2009. Bacchylides. The Victory Poems. Translated with Introduction and Commentary (Bristol)

Mikalson. J.D. 2003. Herodotus and Religion in the Persian Wars (Chapel Hill)

Mitchell, L.G. 1997. Greeks Bearing Gifts: the Public Use of Private Relationships in the Greek World, 435-323 BC (Cambridge) 
Nagy, G. 1979. The Best of the Achaeans: Concepts of the Hero in Archaic Greek Poetry (Baltimore)

Parker, R. 1997. Gods Cruel and Kind: Tragic and Civic Theology, in: Pelling, C. Greek Tragedy and the Historian (Oxford), 143-160

Parker, R. 1998. Pleasing Thighs: Reciprocity in Greek Religion, in: Gill, Postlethwaite and Seaford (eds.), 105-126

Parker, R. 2001. Through a Glass Darkly: Sophocles and the Divine, in: J. Griffin (ed.), Sophocles Revisited. Essays Presented to Sir Hugh Lloyd-Jones (Oxford), $11-30$

Peels, S. 2014. HOSIOS. A Semantic Study of Greek Piety (Diss. Utrecht)

Pelling, C. Educating Croesus: Talking and Learning in Herodotus' Lydian Logos, ClAnt 25.1, 141-177

Pulleyn, S. 1997. Prayer in Greek Religion (Oxford)

Rademaker, A.M. 2005. Sophrosyne and the Rhetoric of Self-Restraint: Polysemy \& Persuasive Use of an Ancient Greek Value Term (Leiden)

Saintillan, D. 1996. Du Festin à l'Échange: les Grâces de Pandore, in: Blaise, F., Judet de la Combre, P., Rousseau, P. (eds.) Le Métier du Mythe. Lectures d'Hésiode (Paris), 315-348

Schadewaldt, W. 1926. Monolog und Selbstgespräch (Berlin)

Silk, M.S. 1985. Heracles and Greek Tragedy, G\&R 32, 1-22

Versnel, H.S. 1981. Religious Mentality in Ancient Prayer, in: H.S. Versnel, (ed.) Faith, Hope and Worship (Leiden) 1-64

Versnel, H.S. 2011. Coping with the Gods: Wayward Readings in Greek Theology (Leiden)

West, M. 1997. The East Face of Helicon: West Asiatic Elements in Greek Poetry and Myth (Oxford)

Wilkins, J.M. 1993. Heraclidae. Euripides. With Introduction and Commentary (Oxford)

Yunis, H. 1988. A New Creed: Fundamental Religious Beliefs in the Athenian Polis and Euripidean Drama (Göttingen)

Winnington-Ingram, R.P. 1973. Zeus in the Persae, JHS 93, 210-219

Zacharia, K. 2003. Converging Truths: Euripides' 'Ion' and the Athenian Quest for 
Self-Definition (Leiden)

Zuntz, G. 1955, The Political Plays of Euripides (Manchester) 